\title{
Monitoring implementation of desertification combating plan using geomatics - A case study, districts Dhar and Jhabua, Madhya Pradesh
}

\author{
Dasgupta Arunima*, P S Dhinwa and A S Rajawat \\ Space Applications Centre, Indian Space Research Organisation, Ahmedabad 380 015, India. \\ *Corresponding author. e-mail: darunima83@gmail.com
}

\begin{abstract}
The world's drylands are subject to desertification as a result of extended droughts, climate change, and human activities. Development in drylands depends on addressing degradation of the ecosystem, mainstreaming sustainable natural resources management, and building upon the existing adaptive capacities of communities and institutions. In this regard, recent scientific results aimed to promote sustainable development through action plans for combating desertification. In India, under the Integrated Mission for Sustainable Development (IMSD) programme, remote sensing based integrated land and water resource studies were carried out with an objective to generate locale specific action plans for sustainable development of a region. A specific study was carried out, in districts of Jhabua and Dhar, in Madhya Pradesh using Composite Land Development Sites (CLDS) approach for forest and wasteland development and soil and water conservation. Various treatments were suggested and implemented in 1995. The present study was carried out with an objective to monitor the positive impacts of combating plan implementation through visual interpretation and NDVI analysis of temporal images of LISS III data, since 1991 to 2013. The study reveals that there is substantial increase in the area of irrigated agricultural land with increase in number of check dams along with the stream channels.
\end{abstract}

\section{Introduction}

Combating desertification and land degradation, one of the major challenges worldwide, was first addressed by United Nations Convention to Combat Desertification (UNCCD) in 1994. UNCCD defines desertification as 'Land degradation in arid, semi-arid, and dry subhumid areas resulting from various factors including climatic variations and human activities', where 'land' is defined as terrestrial bio-productive system and 'land degradation' is defined as reduction or loss in biological and economic productivity (UNCCD 1994). Most likely, the true level of degradation in drylands lies somewhere between 10\% (MA 2005) and
20\% (GLASOD 1990), and over 250 million people are directly affected by land degradation (Reynolds et al. 2007; UNCCD 1994). About 228.3 mha (69\%) of India's total geographical area is under drylands and 105.8 mha (25\%) areas of our country have been affected by desertification (SAC 2007). This is a complex phenomenon which causes progressive loss in biological quality and productivity of land. It has a direct impact on land and other natural resources, which results in reduced agricultural productivity, loss of biodiversity and vegetative cover, and a decline in the availability of water in the affected region. All these lead to a decline in the quality of life, eventually affecting the socio-economic status of the people in affected

Keywords. Combating desertification; integrated CLDS approach; plan implementation; NDVI; increase in water body and agriculture. 
regions. It is therefore important that, issues of environmental protection are given high priority and the negative consequences of environmental degradation are considered and addressed effectively for sustainable development. In this context, UNCCD was adopted in 1994, with an aim to combat desertification occurring in the dryland regions of the world and to mitigate the effects of drought. The convention stresses the need for integrated efforts and long-term strategies on various crosssectoral environmental and economic issues leading to several developmental activities for the local communities to improve their living standards. Thus UNCCD provides a platform for addressing these issues in both, the national and global context (Jayakrishnan 2001). Research programs during the last 25 years have focused on evolving specific strategies for improving productivity through a judicious blend of land, water, and crop management practices (MoEF 2001). The country has a rich history of use of traditional systems of water harvesting. Though conservation of both, surface and groundwater, has been an integral part of Indian practices for many centuries through village level water harvesting tanks, research during the last 25 years has led to standardizing the variable with respect to catchment size of the droughts and utilization of stored water. Some of these programmes were Notational Watershed Project for Rainfed Area (NWDPRA), Watershed Development Project for Shifting Cultivation Area (WDPSCA), Integrated Wasteland Development Project (IWDP), Desert Development Programme (DDP), Drought Prone Area Programme (DPAP), Integrated Afforestation and Eco-development Project Scheme (IAEPs), etc. (MoEF 2001). Realizing the importance of adopting an integrated approach, and recognizing the mutual interdependencies of natural resources, the Department of Space (DOS), at the behest of the Planning Commission, Govt. of India has taken up a major programme - Integrated Mission for Sustainable Development (IMSD), along with various state and central government agencies. Under this mission it is proposed to undertake remote sensing based integrated land and water resource studies for various problem districts of the country, among which Jhabua and Dhar districts of Madhya Pradesh were selected as having priority in DPAP. Composite Land Development Sites (CLDS) approach was applied with the aid of remote sensing satellite data, other ancillary information, and GIS environment for implementing various watershed management plans in the selected region. The suitability of various CLDSs was evaluated for agriculture, forest and wasteland development, soil and water conservation, and various treatments were suggested and implemented in 1995.
The districts of Dhar and Jhabua fall in the semiarid tropics of India. Conservation of soil, efficient management and utilization of rainwater, and management of the non-arable lands for fodder, fruit and fuel wood production in the watershed perspective are the core strategies of natural recourse management in the semi-arid tropics of India. All these water conservation measures are aimed to increase soil moisture, reduce surface runoff and erosion, recharge ground water in the discharge zone, and utilize ground water as well as rainwater for crop growth more effectively (MoEF 2001).

Implementation of resource management plans, like desertification combating measures includes brainstorming researches with improved technological use and appropriate decision making processes, which in turn use a good amount of the nation's finance. In addition, in a developing country like India, failure of such an implementation cannot be accepted in the context of high population density and overutilization and misuse of resources. Thus monitoring these kinds of implementations is important. It is necessary that the means of monitoring be very objective and unbiased. As remote sensing and GIS have been employed to assess the resource status for the purpose of generating action plans, it is appropriate that the same means should be used to the extent possible for the purpose of monitoring too. Keeping this view, the parameters which were indentified for monitoring purposes are: LULC parameters, extent of irrigated area, vegetation index, fluctuation in depth of groundwater table, well density and yield, cropping pattern and yield, occurrence of hazards, and related socio-economic indicators (IMSD 1995).

The present study is carried out with an objective to monitor the positive impacts of desertification combating methods through changes in surface water bodies, areal extent in irrigated agriculture, and changes in NDVI values of agricultural lands, in the districts of Jhabua and Dhar in Madhya Pradesh. For achieving this objective, first the CLDS approach was explained. Then positive changes in surface water bodies as well as in irrigated agriculture are evaluated both quantitatively and qualitatively using visual interpretation and NDVI analysis.

\section{Study area}

Districts of Jhabua and Dhar of Madhya Pradesh state were selected as the study area (figure 1). The total area of these two districts extends from about $23^{\circ} 55^{\prime}$ to $23^{\circ} 14^{\prime} \mathrm{N}$ latitude and from $74^{\circ}$ to $74^{\circ} 42^{\prime} \mathrm{E}$ longitude. These districts were identified in DPAP as priority districts. It is pertinent to note here that 


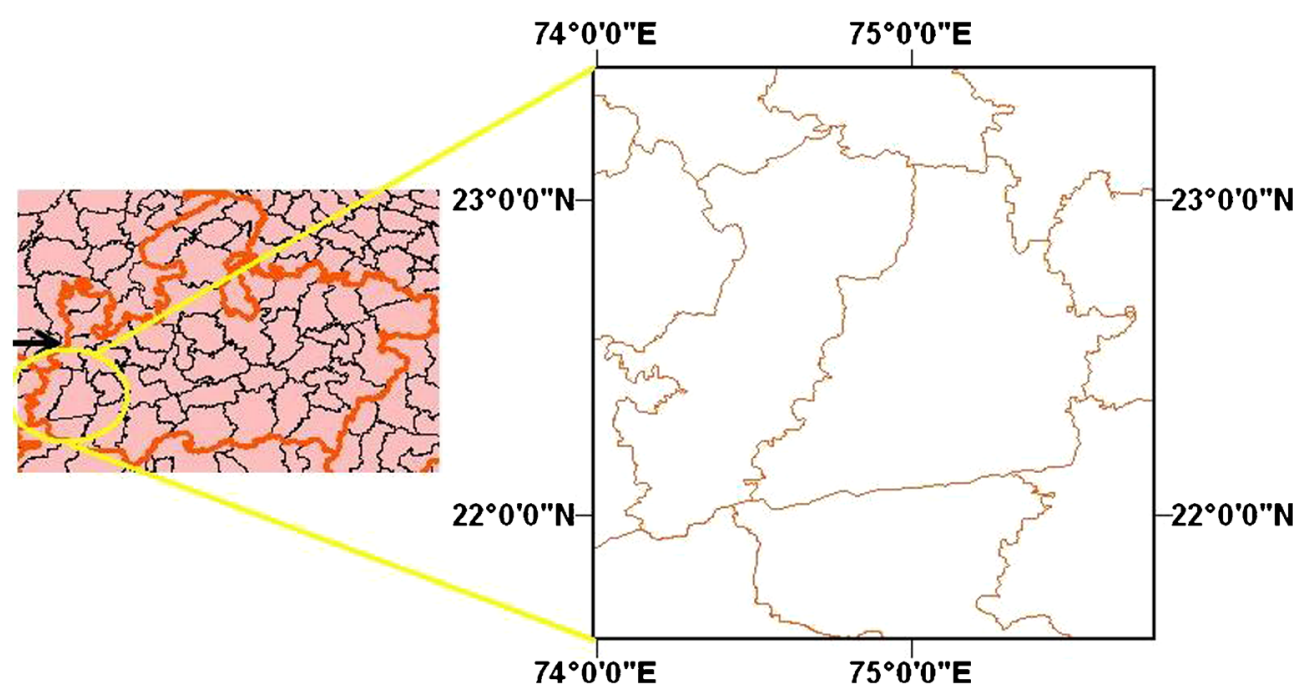

Figure 1. Study area, districts Jhabua and Dhar, located in southwestern corner of Madhya Pradesh state, India.

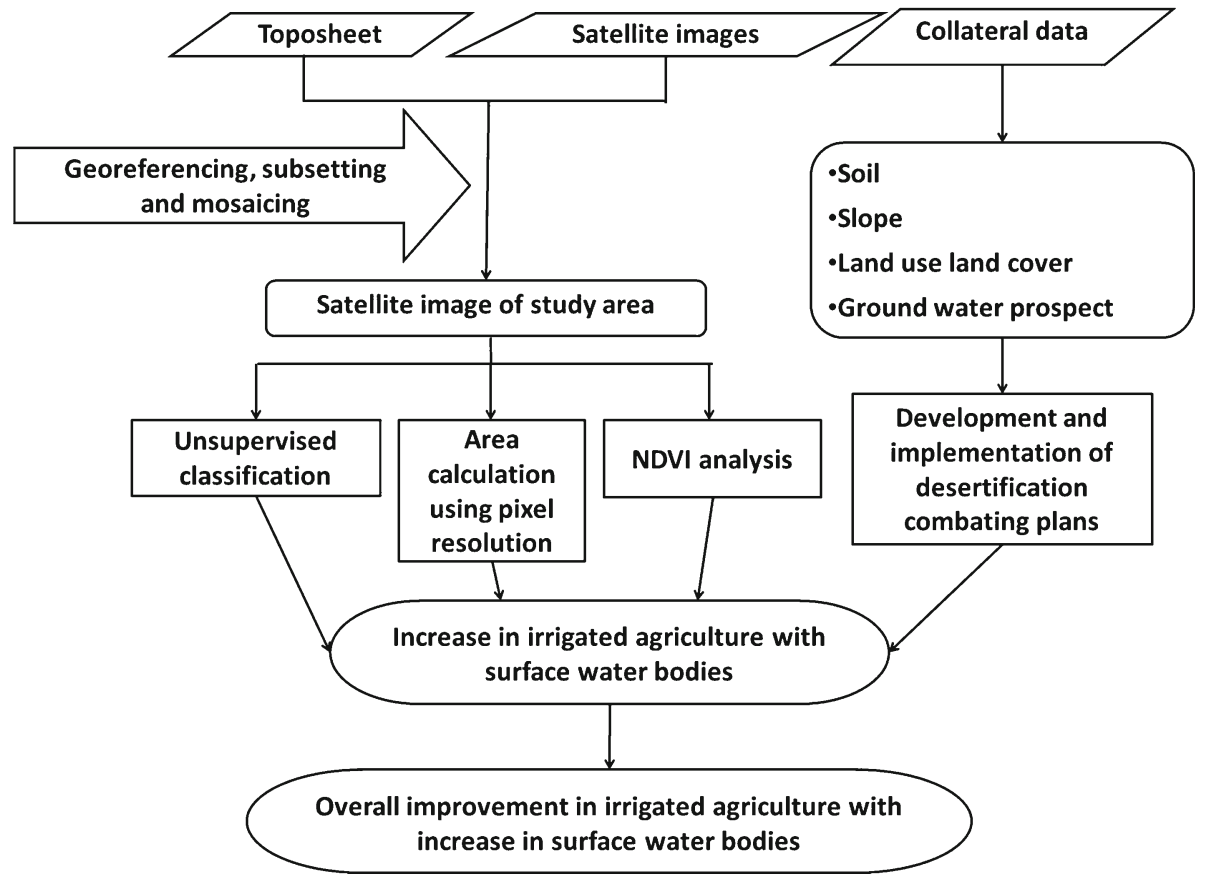

Figure 2. Flowchart showing overall methodology used for the study.

during the past few years, these districts have faced drought several times. Added to this, the relentless exploitation of the natural resources in the form of soil cover, vegetative cover, and ground water due to increased biotic pressure mounted pressure on the fragile eco-system. Rural poverty and extensive unemployment amongst the casual farm and non-farm workers indicate inadequate work opportunities. As a consequence, the livelihood of rural people in agricultural areas has always been under constant threat.

In the context of the above background, watershed management programme is the most appropriate and scientific approach for conserving the soil and water resources and optimizing their utilization to have increased/sustainable agricultural productivity, regeneration of natural vegetation, and better livelihood opportunities. The Ministry of Rural Development, Govt. of India had started watershed management programme in the year 1994 under Drought Prone Area Programme (DPAP), Employment Assurance Scheme (EAS), and Integrated Wasteland Development Programme (IWDP).

Considering its importance, Government of Madhya Pradesh, Panchayat and Rural Development Department had also constituted Rajiv Gandhi Mission for Watershed Management 

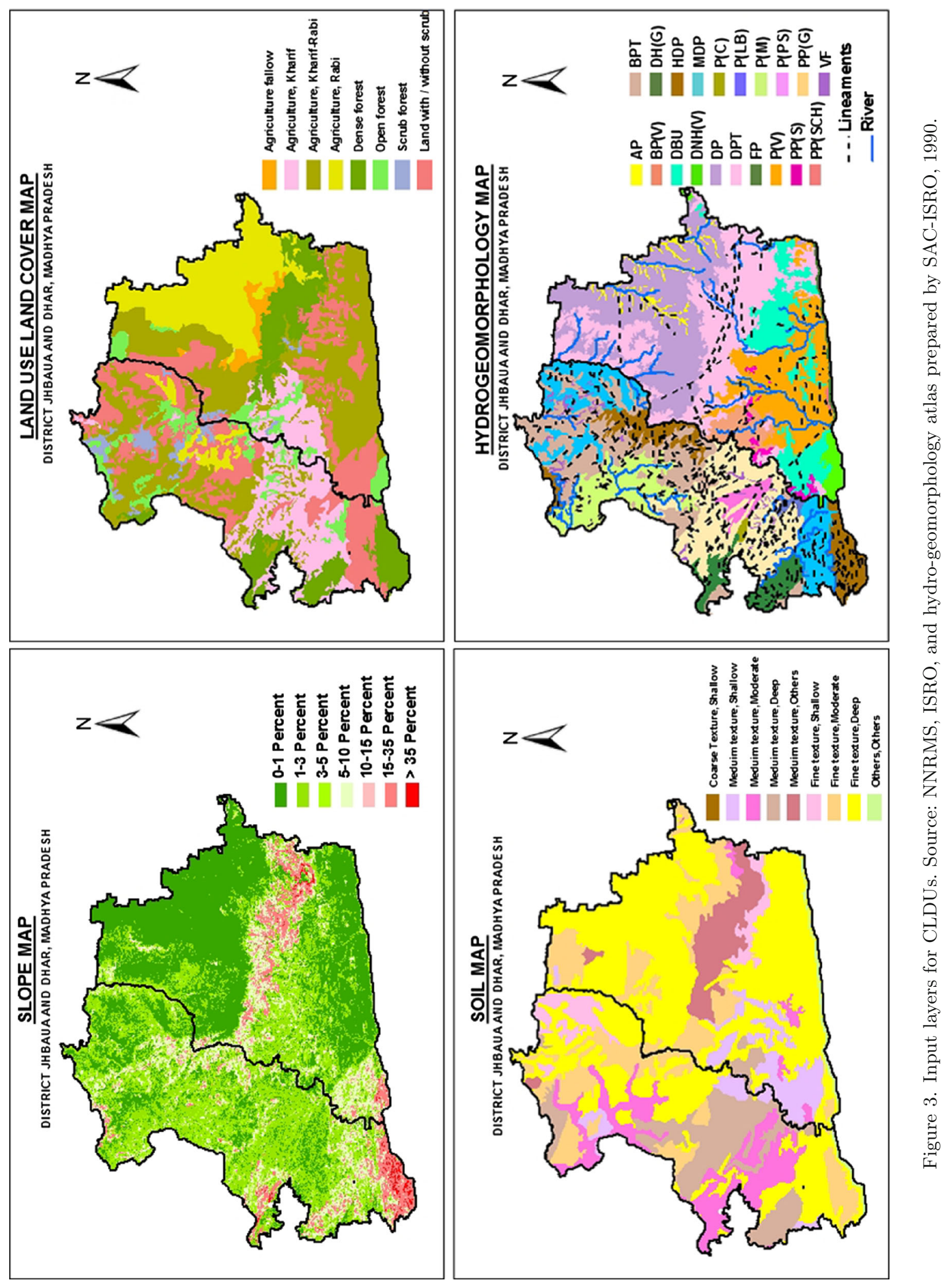


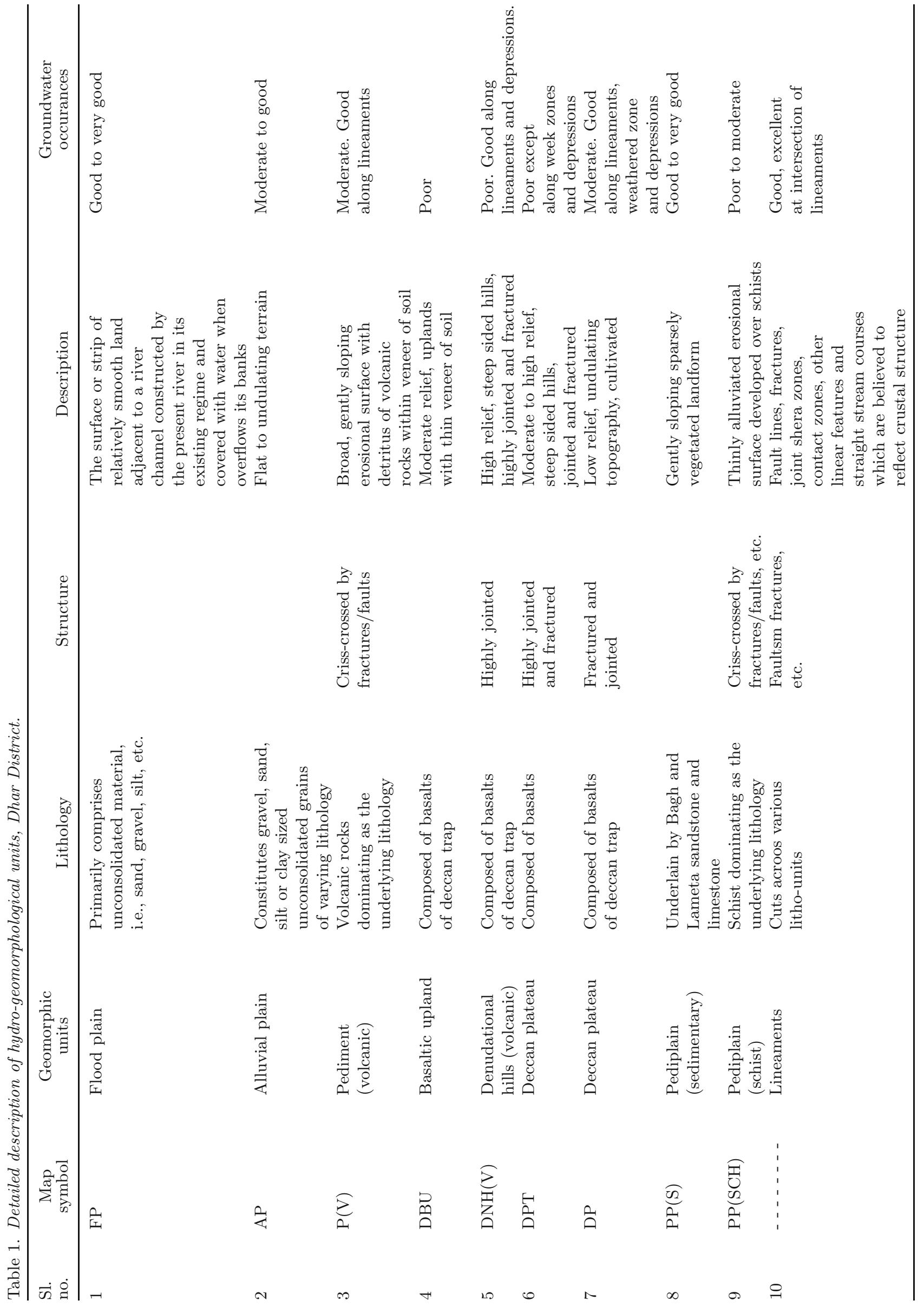




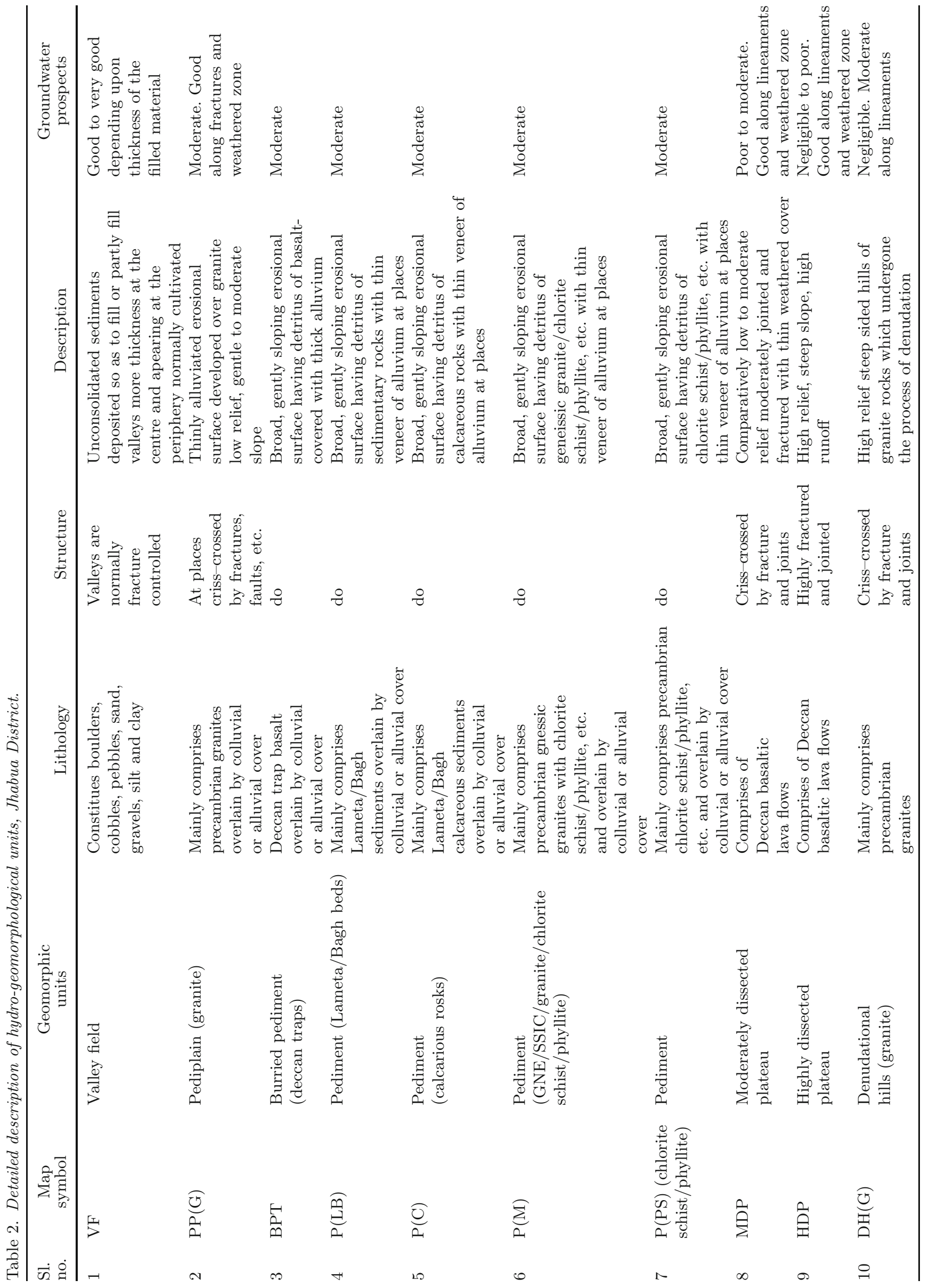




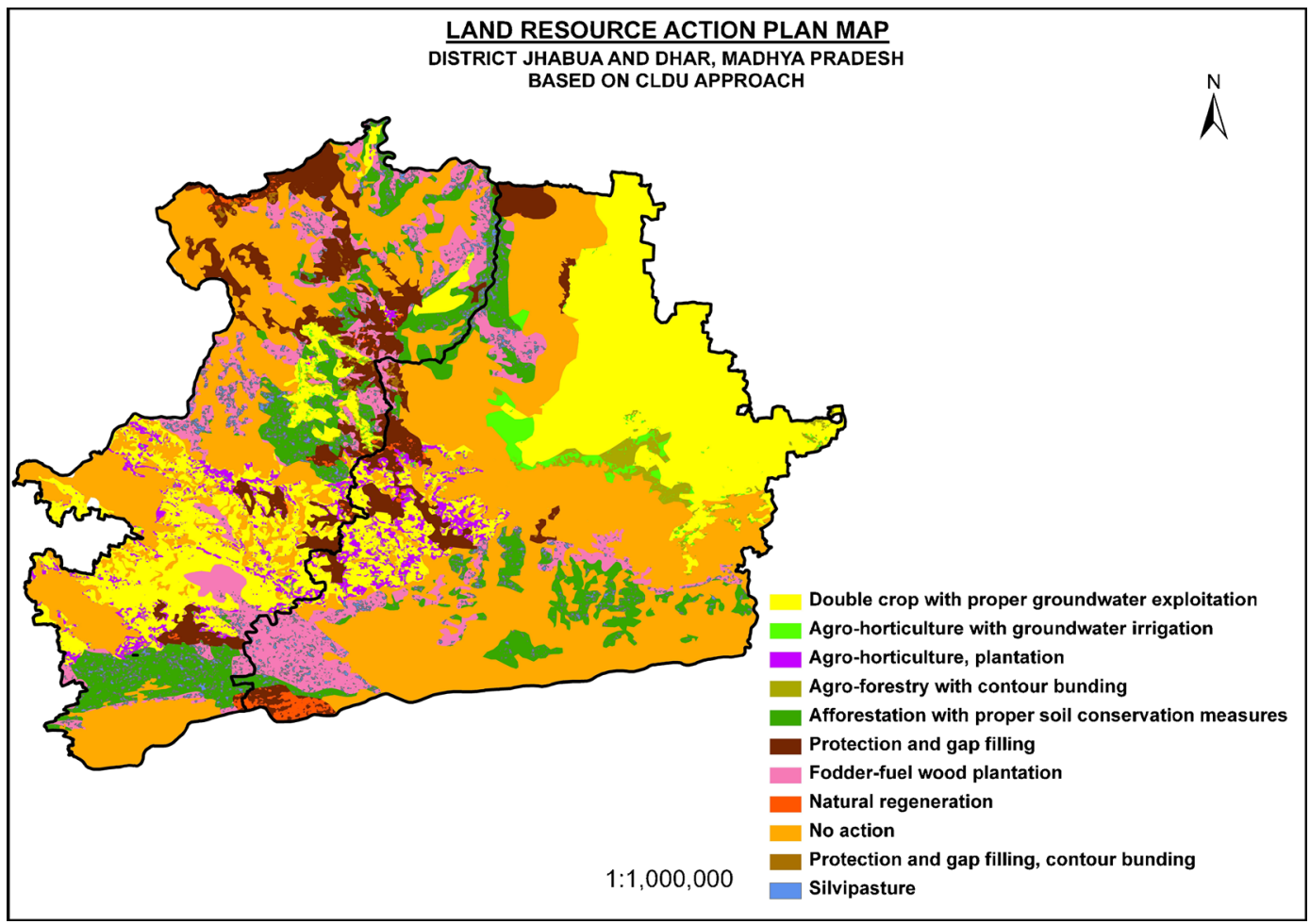

Figure 4. Land resources action plan map for Jhabua and Dhar districts, MP.

Table 3. Recommended decisions rules for land resources development plan (IMSD 1995).

\begin{tabular}{|c|c|c|c|c|c|}
\hline No. & $\begin{array}{l}\text { Land use/land } \\
\text { cover }\end{array}$ & $\begin{array}{l}\text { Ground water } \\
\text { prospect }\end{array}$ & $\begin{array}{l}\text { Slope in } \\
\text { percent }\end{array}$ & $\begin{array}{c}\text { Land } \\
\text { capability }\end{array}$ & Measures \\
\hline 1 & Scrub forest & Poor & $5-10$ & VI & $\begin{array}{l}\text { Afforestation with proper } \\
\text { soil and water conservation }\end{array}$ \\
\hline 2 & $\begin{array}{l}\text { Kharif+Rabi, } \\
\text { Dense forest }\end{array}$ & Good & $3-5$ & III & No action \\
\hline 3 & Open forest & Moderate-poor & $5-10$ & VI & Protection and gap filling \\
\hline 4 & Open forest & Moderate & $>35$ & VI & $\begin{array}{l}\text { Afforestation with } \\
\text { staggered trenches }\end{array}$ \\
\hline 5 & Crop land in forest & Moderate & $0-3$ & III & $\begin{array}{l}\text { Agro-forestry with contour } \\
\text { bunding }\end{array}$ \\
\hline 6 & Kharif crop & Moderate & $0-3$ & I\&III & $\begin{array}{l}\text { Double cropping with } \\
\text { ground water exploration }\end{array}$ \\
\hline 7 & Kharif crop & Moderate & $3-5$ & IV & $\begin{array}{l}\text { Agro-horticulture with } \\
\text { groundwater irrigation }\end{array}$ \\
\hline 8 & Double crop & Good-moderate & $0-1$ & III & $\begin{array}{l}\text { Minimal action - farm } \\
\text { ponds }\end{array}$ \\
\hline 9 & $\begin{array}{l}\text { Land with scrub and } \\
\text { land without scrub }\end{array}$ & Moderate-poor & $10-15$ & IV & Silvipasture \\
\hline 10 & $\begin{array}{l}\text { Barren rocky/stony } \\
\text { waste/sheet rock area }\end{array}$ & Poor & $\begin{array}{l}5-10 \& \\
10-15\end{array}$ & VIII & Natural regeneration \\
\hline 11 & $\begin{array}{l}\text { Wasteland } \\
\text { Salt affected land }\end{array}$ & Moderate & $3-5$ & III & Drainage treatment \\
\hline 12 & Open forest & Moderate-poor & $3-5$ & VI & $\begin{array}{l}\text { Afforestation with contour } \\
\text { bunding }\end{array}$ \\
\hline
\end{tabular}


Table 4. Recommended decision rules for water resources development plan (Adiga and Krishna Murthy 2000; Shankar and Mohan 2005).

\begin{tabular}{|c|c|c|c|c|c|}
\hline $\begin{array}{l}\text { Specific } \\
\text { activity }\end{array}$ & $\begin{array}{l}\text { Slope } \\
(\%)\end{array}$ & Land use & $\begin{array}{l}\text { Soil } \\
\text { permeability }\end{array}$ & Drainage & Favourable conditions \\
\hline Check dams & $<5 \%$ & $\begin{array}{l}\text { River stream } \\
\text { (near by } \\
\text { moderate to } \\
\text { highly up to } 3 r d \\
\text { order. Catchment } \\
\text { area should be } \\
\text { around } 25 \text { ha } \\
\text { agricultural land) }\end{array}$ & $\begin{array}{l}\text { Moderate to } \\
\text { highly permeable }\end{array}$ & $\begin{array}{l}\text { Up to } 3 r d \\
\text { order }\end{array}$ & $\begin{array}{l}\text { - Catchment area should be } \\
\text { around } 25 \text { hectares } \\
\text { - Presence of irrigation wells } \\
\text { in the downstream of the } \\
\text { proposed structure, P } \\
\text { - Referable in the areas having } \\
\text { high watertable fluctuations } \\
\text { - Areas closer to lineaments }\end{array}$ \\
\hline $\begin{array}{l}\text { Nala bunds and } \\
\text { percolation tank }\end{array}$ & $0-2 \%$ & $\begin{array}{l}\text { Open land/waste } \\
\text { land drainage } \\
\text { coarse }\end{array}$ & $\begin{array}{l}\text { High soil } \\
\text { permeability }\end{array}$ & $\begin{array}{l}\text { 2nd and } \\
\text { 3rd order }\end{array}$ & $\begin{array}{l}\text { - Stream bed can also used if } \\
\text { sufficient drainage course } \\
\text { catchment is available } \\
\text { - Preferred near the } \\
\text { perennial streams } \\
\text { - Lineaments/fracture zones } \\
\text { preferable }\end{array}$ \\
\hline $\begin{array}{l}\text { Underground barrier } \\
\text { or subsurface dyke }\end{array}$ & $0-3 \%$ & River bed & $\begin{array}{l}\text { High soil } \\
\text { permeability }\end{array}$ & $\begin{array}{l}4 \text { th }-7 \text { th } \\
\text { order }\end{array}$ & $\begin{array}{l}\text { - Preferable in areas where } \\
\text { thickness of river bed is } \\
\text { greater than } 5 \mathrm{~m} \text {, sandy } \\
\text { and gravel bed } \\
\text { - Across the streams which } \\
\text { flow linearly for a } \\
\text { considerable distance } \\
\text { - Sufficiently wide stream } \\
\text { bed perennial streams }\end{array}$ \\
\hline Farm pond & $0-3 \%$ & Agricultural area & $\begin{array}{l}\text { Low } \\
\text { permeability }\end{array}$ & $\begin{array}{l}\text { 1st order } \\
\text { or sheet } \\
\text { wash area }\end{array}$ & $\begin{array}{l}\text { - Lineament or fracture } \\
\text { zones should be avoided }\end{array}$ \\
\hline
\end{tabular}

Table 5. Increase in areal extent of irrigated agricultural land with simultaneous increase in number and area water bodies, districts Jhabua and Dhar, LISS II and LISS III images of 1991 and 2013, respectively.

\begin{tabular}{lcccccc}
\hline $\begin{array}{l}\text { NDVI values/ } \\
\text { Year }\end{array}$ & Minimum & Maximum & Mean & $\begin{array}{c}\text { Standard } \\
\text { deviation }\end{array}$ & Kurtosis & $\begin{array}{c}\text { Peak } \\
\text { values }\end{array}$ \\
\hline 1991 & 0.002 & 0.48 & 0.24 & 0.23 & -1.13 & $0.2-0.4$ \\
2013 & 0.002 & 0.7 & 0.34 & 0.20 & -1.20 & $0.4-0.6$ \\
\hline
\end{tabular}

(RGMWM) in August 1994 to plan and implement the watershed projects in mission mode with the aim of reducing the vulnerability to droughts, improving the income and livelihood of people and also providing short-term employment opportunities. Various water harvesting measures were initiated and implemented aiming to increase agriculture through increase in surface and subsurface water. Increase in agricultural production with proper soil and water management practices increase the carrying capacity of the land leading to sustainable development.

The whole study area falls in the hot, moist semiarid agro-ecological subregion $\left(15 \mathrm{Dm} 4^{1}\right)$, which

\footnotetext{
${ }^{1} 15 \mathrm{Dm} 4$ indicates the particular agro-ecological subregion with its physiography, soil, bioclimate and length of growing period. In this case 15 implies brown forest and podzolic soils and Dm4 implies moist semi-arid bioclimate with 120150 days of LGP (length of growing period) (Velayutham et al. 1999).
} 


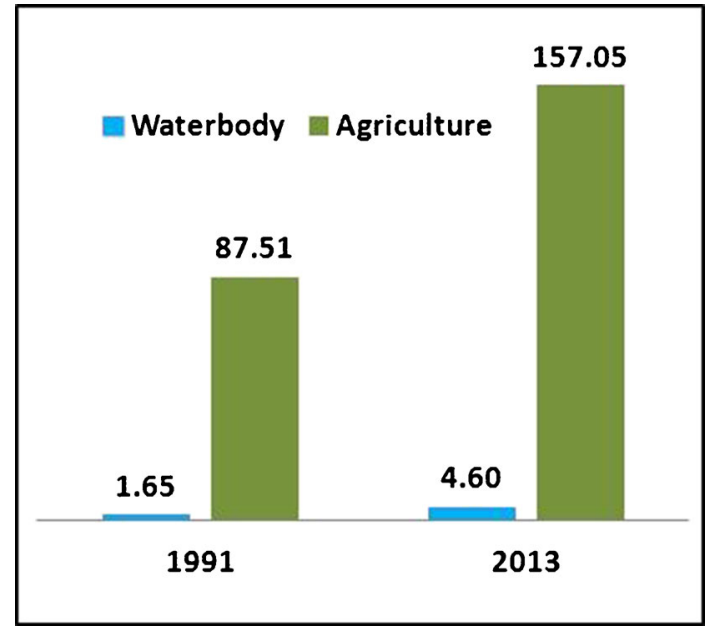

Figure 5. Areal change in water bodies and irrigated agricultural land in the study area, based on IRS LISS II (1991) and IRS LISS III (2013) images.

is characterized by dry summers and mild winters. Both the districts are part of Malwa plateau formed of Deccan Trap rock. The dominant soils of this area are represented by Sarol series and Kamliakheri series, which are moderately deep, moderately well drained, and moderately permeable black soil. The natural vegetation comprises tropical dry and mixed deciduous forest. Dryland farming is a common traditional practice in highly undulating topography in Jhabua, with slopes of cultivated lands. This area is mostly habitated by tribals engaged in tribal agriculture. Among the cereal crops maize occupies the largest area followed by Jowar. Rice is also cultivated in small areas (Velayutham et al. 1999).

\section{Methodology}

The study is carried out in two major stages. The first to explain CLDS approach for generating action plans to combat desertification. The second, to analyze the positive impacts of those implemented action plans suggested by CLDS approach in districts of Jhabua and Dhar, under IMSD project. The overall methodology has been explained in figure 2 .

The main objective of combating desertification is to generate action plans for the area which are optimally suitable to the terrain and to the productive potential of the local resources so that the level of production is sustained without decline over time (IMSD 1995). For this purpose, Composite Land Development Sites (CLDS) method was evolved and applied. CLDS is an integrated method incorporating three major steps. First, four thematic maps (figure 3) were generated, namely soil, slope, land use/land cover, and ground water potential (derived from hydro-geomorphology map), representing individual classes of these parameters, for any given problem area. Then this information was combined both spatially and aspatially, using GIS techniques for obtaining unique CLDSs. Each CLDS has its unique combination of four parameters as mentioned before. In final stage, combating action plans are suggested for sustainable development of each CLDSs, and thus for the whole problem area.

The detailed description of the hydro-geomorphology map of Dhar and Jhabua are given in tables 1 and 2 .

For districts of Jhabua and Dhar, thematic maps of soil, land use/land cover, and hydro-geomorphology (figure 3) were prepared using visual interpretation of temporal IRS LISS II images (1992-1994) and ancillary information (geological maps, toposheets, published literature, and field survey). Slope map (figure 3) was generated from topographic sheet. Slope, soil, land capability, and ground water prospect information were integrated in GIS environment to generate CLDS map (figure 4). Various combating measures were suggested and implemented (IMSD 1995). High priority was given to vegetative measures like afforestation, growing grasses, agro-forestry, contour bunding, horticulture fuel-fodder, and fruit plantation, etc., to prevent soil erosion and increase soil capacity to retain water (figure 4, table 3). In addition, site specific water resource development actions were proposed, like making check dams, nallah bunds, stop damcum-surface dukes, culvert-cum-stop dams, etc., to increase soil moisture, reduce run off and erosion, recharge ground water, promote proper ground water exploitation, and increase surface water storage (table 4). Some of the water harvesting measures are described below (Rao et al. 2005).

\subsection{Check dams}

Check dams are very popular water harvesting structures and are also very important since they control soil erosion. In general, they are constructed at lower order stream (up to third order); the slope of the terrain should be flat to gentle so as to retain maximum quantity of water with less height of check dams. They are proposed in areas where water table fluctuations are very high and the stream is influent and/or internally effluent. To have an economical design, the catchment area should be more than 25 ha. The soil should be less to medium permeable to allow some recharge to the downstream side of the dam if necessary. It should be located near agriculture and settlement areas to convey the harvested water. 
Table 6. Statistical specifications for NDVI values of agricultural area, districts Jhabua and Dhar, LISS II and LISS III image of 1991 and 2013, respectively.

\begin{tabular}{|c|c|c|c|c|c|c|}
\hline $\begin{array}{l}\text { NDVI values/ } \\
\text { Year }\end{array}$ & Minimum & Maximum & Mean & $\begin{array}{l}\text { Standard } \\
\text { deviation }\end{array}$ & Kurtosis & $\begin{array}{c}\text { Peak } \\
\text { values }\end{array}$ \\
\hline 1991 & 0.002 & 0.48 & 0.24 & 0.23 & -1.13 & $0.2-0.4$ \\
\hline 2013 & 0.002 & 0.7 & 0.34 & 0.20 & -1.20 & $0.4-0.6$ \\
\hline
\end{tabular}

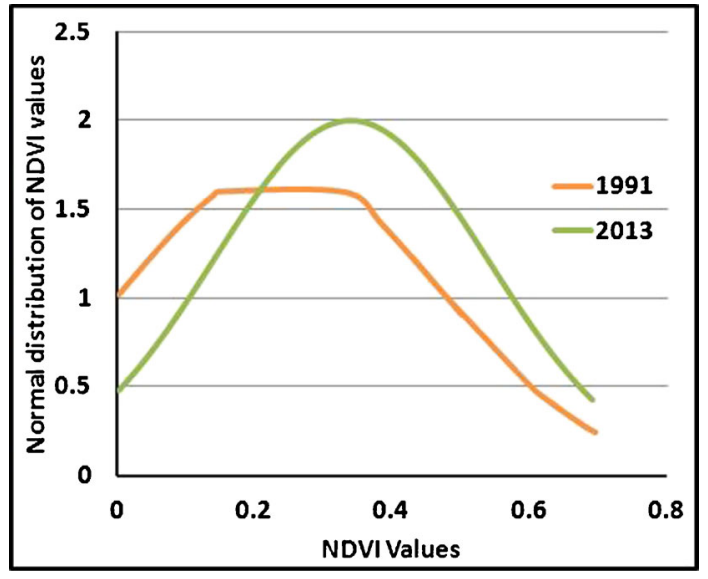

Figure 6. Normal distribution of NDVI values in agricultural land, Districts Jhabua and Dhar, LISS II and LISS III image of 1991 and 2013, respectively.

\subsection{Farm ponds}

Farm ponds are made either by constructing an embankment across a watercourse or by excavating a pit or the combination of both. Normally such structures are provided in individual farms. Generally excavation will take place in areas having flat topography and low soil permeability. Farm ponds should be free from any faults, preferably near agricultural areas.

\subsection{Water harvesting Bundhis}

Bundhis (local name in India) are almost similar to the minor irrigation tanks except that they do not have an extensive canal system and their command area is limited to the field of downstream. They should not be located in impervious strata, which may hinder groundwater recharge. There should be adequate good cultivable land in the downstream of the Bundhi to reap the benefit of the water stored. Slopes of the area should be less to moderate.

\subsection{Nala bunds and percolation tanks}

Nala bunds and percolation tanks are structures constructed across or near Nalas (streams) for checking velocity of runoff, increasing water percolation, increasing soil moisture regime, and to hold the silt flow. The sites feasible for such construction should be selected in relatively flatter Nala reach, with slope being not more than $2 \%$. The catchment area of the percolation tank should be at least 40 ha and there should be proper site for construction of emergency spillway by the side of the Nala bund. The soils should have adequate permeability and good fracture development to facilitate potential recharge.

\subsection{Ground water recharge structure}

These types of structures are constructed for the purpose of enhancing the ground water potential of the area under consideration. Groundwater recharge can be done by flooding the suitable areas or by constructing infiltration wells. In case of infiltration wells, water has to be diverted from streams by unlined canals to felicitate more recharge. These structures are generally constructed on active aquifers and on scrub or barren land. Slope of the area should not be more than $5 \%$ and soil should be highly permeable. Sufficient land area should be available for constructing these structures.

The second stage of the study involves analysis of positive impact of desertification combating measures through changes in surface water bodies, areal extent in irrigated agriculture, and changes in NDVI values of agricultural lands. Increase in surface water bodies is evaluated by visual interpretation of satellite image. Increase in extent in irrigated agricultural land is calculated as per the pixel resolution of the individual images. Vegetation index is analyzed from positive changes in NDVI values. For NDVI analysis, first the DN value images were converted to spectral radiance image, and further to apparent reflectance image (Lillesand and Kiefer 2000). NDVI image was generated from this apparent reflectance image. Negative values were omitted from the study. Multidate satellite images (LISS II images of 1991 and LISS III images of 2013) of the month of February are used for the study along with ancillary data. Satellite images are georeferenced in UTM projection with WGS 84 datum. Image subsetting and mosaicing are performed as per the requirement of the study. The agricultural lands and water bodies are delineated from LISS II and LISS III images for the agricultural lands of 1991 and 2013, respectively. 

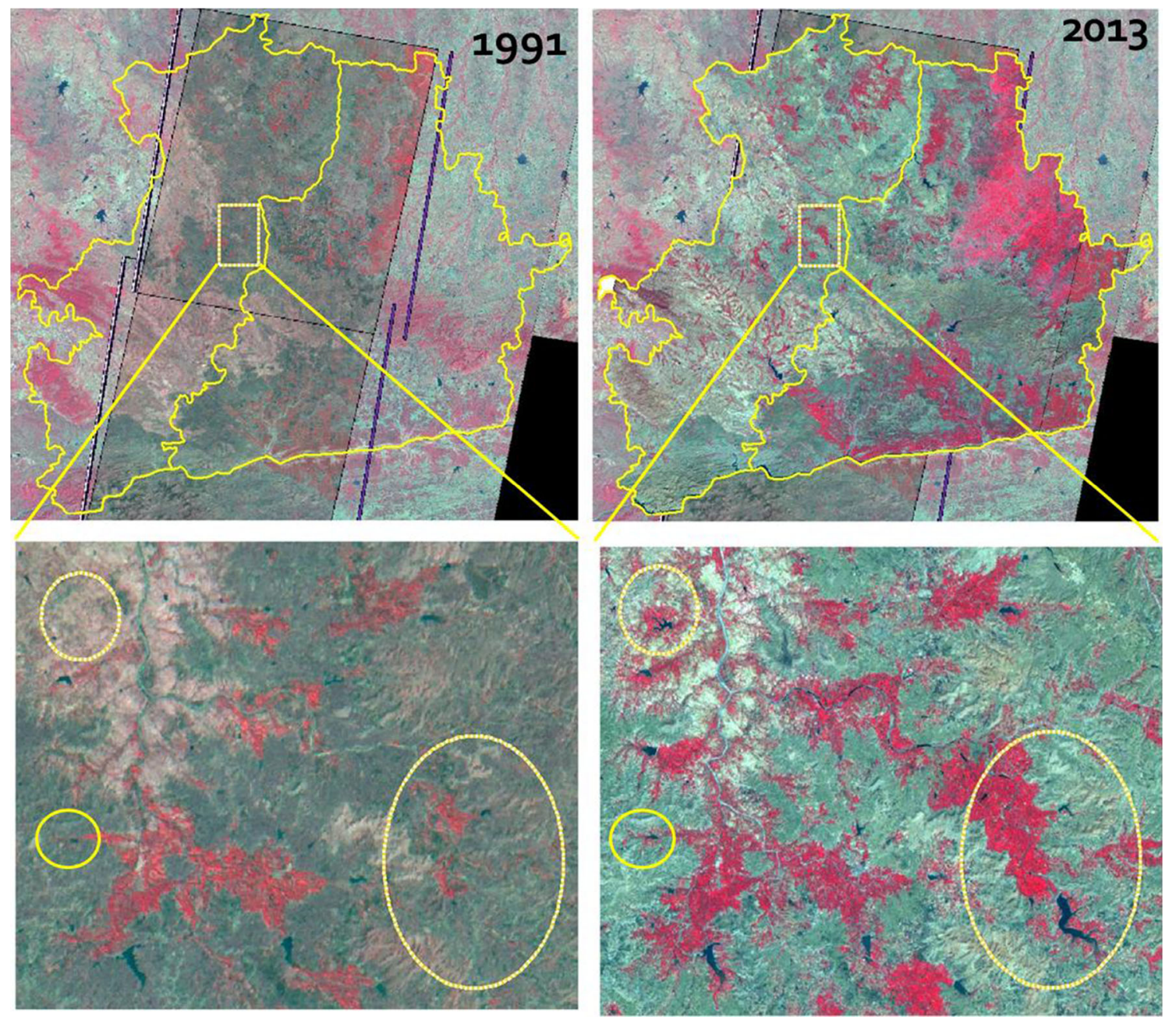

Figure 7. An example of newly formed waterbody in Jhabua district, resulting in an increase in agriculture, was identified in LISS III image of 2013, which was not in LISS II image of 1991.

\section{Analysis and results}

\subsection{Increase in surface water bodies}

The number of water bodies increased from about 103 to 270 and the area of a water body increased from about 1.65 to $4.6 \mathrm{~km}^{2}$, during 1991 to 2013 , as depicted from LISS II and LISS III images of 1991 and 2013 respectively (table 5, figure 5).

\subsection{Increase in extent of agricultural land}

Areal extent of agricultural land is calculated as per the pixel resolution of the individual images (41 $\mathrm{m}$ for LISS II and $24 \mathrm{~m}$ for LISS III²). In 1991

\footnotetext{
${ }^{2}$ The spatial resolution of LISS II and LISS III images are 36.25 and $23.5 \mathrm{~m}$, respectively. But the images used for the study were resampled in the resolution as stated, $41 \mathrm{~m}$ for LISS II and $24 \mathrm{~m}$ for LISS III. This information was gained from the image information obtained from various image processing softwares (ERDAS IMAGINE and ENVI) and also from the manual calculation of the distance between two known locations divided by the pixel numbers.
}

the area was about $87.5 \mathrm{~km}^{2}$, which increased upto about $157 \mathrm{~km}^{2}$ in 2013 (table 5, figure 5).

\subsection{Positive changes in NDVI values of agricultural land}

For evaluating the qualitative increase in agriculture, NDVI analysis was carried out. The fundamental behind NDVI is that the internal mesophyll structure of healthy green leaves strongly reflects NIR radiation and leaf chlorophyll and other pigments absorb a large proportion of the red VIS radiation. Therefore, higher photosynthetic activity will result in lower reflectance in the red channel and higher reflectance in the near-infrared channel. This signature is unique to green plants. This becomes reverse in case of unhealthy or water stressed vegetation. Thus vegetation vigour can be portrayed in NDVI, which can be obtained from following the formula $\mathrm{NDVI}=(\mathrm{IR}-\mathrm{R}) /(\mathrm{IR}+\mathrm{R})$, where, IR and $\mathrm{R}$ are the reflectance value of pixels in infra-red and red band, respectively (Tucker 1979; Jackson et al. 1983; Tucker et al. 1991). 

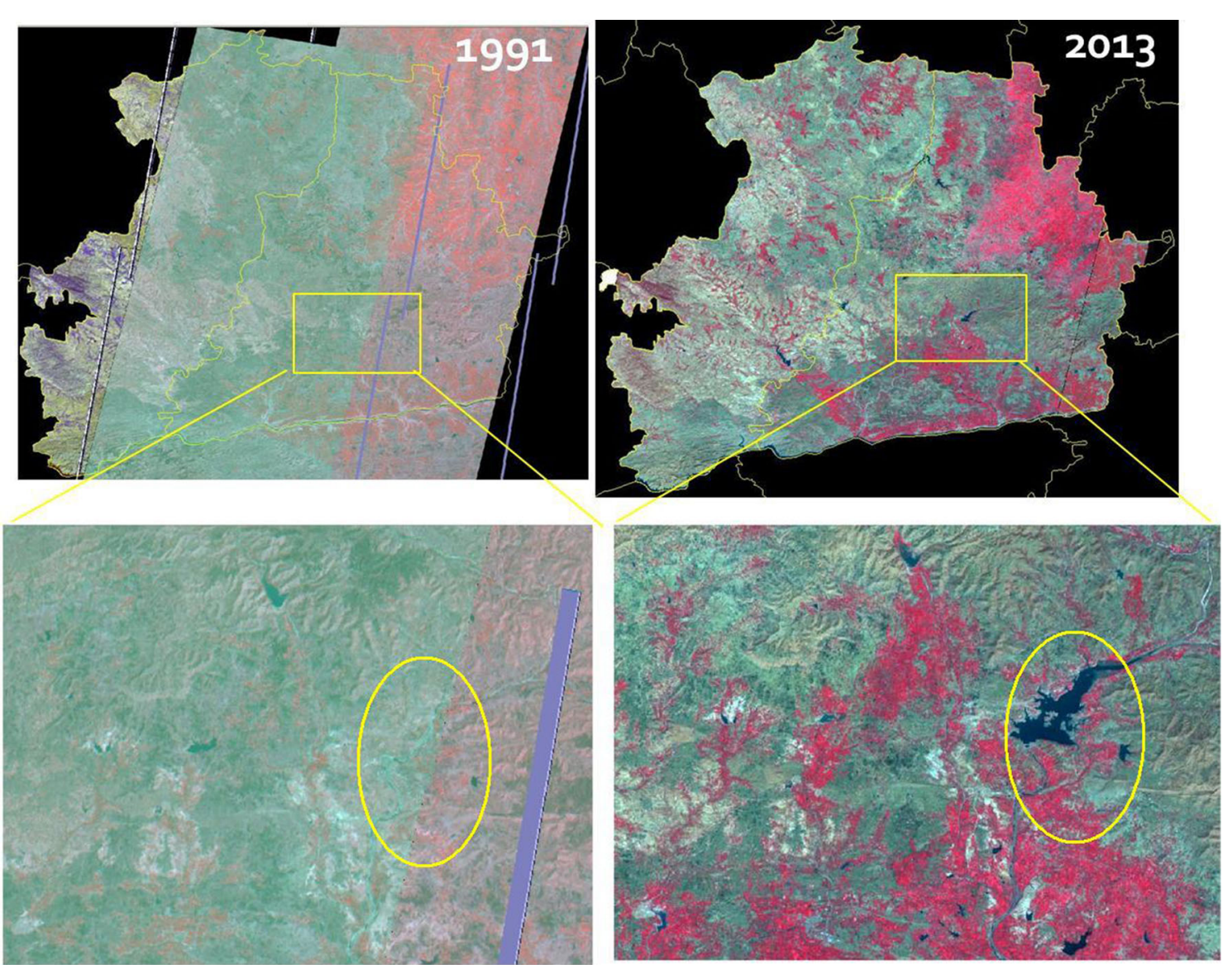

Figure 8. An example of newly formed waterbody in Dhar district, resulting in an increase in agriculture, was identified in LISS III image of 2013, which was not in LISS II image of 1991.

NDVI values range between -1 and +1 . The NDVI values of vegetation ranges from 0 to 1 , representing different chlorophyll content, indicating the health status of vegetation. Generally, healthy vegetation absorbs most of the visible light that falls on it and reflects a large portion of the nearinfrared light. Unhealthy or sparse vegetation reflects more visible light and less near-infrared light.

Only for agricultural areas, NDVI ranged from 0.002 to 0.48 with mean value 0.24 and standard deviation 0.23 in 1991. In 2013, NDVI ranged from 0.002 to 0.7 with mean value 0.34 and standard deviation 0.20 . The kurtosis was -1.13 in 1991 and -1.20 in 2013 (table 6 ). The normal probability density function of NDVI values were plotted in y-axis with respect to the corresponding NDVI values in $\mathrm{x}$-axis to get a smooth curve for better representation. A positive shift in the peak observation of NDVI values can be inferred from the graphical representation of NDVI. In 1991, it was between 0.2 and 0.4 whereas in 2013 , it increased to 0.5 (figure 6). The skewness of the dataset (NDVI values) is 0.97 in 1991, whereas it is almost nil (0.0017) in 2013.

Two such examples are shown in figures 7 and 8, where increase in agriculture can be observed clearly with occurrences of new water bodies in the images of 2013 as compared to the images of 1991.

\section{Conclusions}

IMSD study was initiated in the year 1987 with specific reference to find scientific and lasting solution to mitigate drought (SAC 1995). Drought has been a recurring feature in Indian agriculture during 1991 to 2000 and also earlier. These districts suffered from crop losses and distress. Various issues such as prevention and mitigation of distress caused by drought were addressed and appropriate technologies for soil and water management and conservation measures were developed and implemented in various drought prone districts of India, among which Jhabua and Dhar districts were selected for this study.

The present study was carried out to establish the positive impact of desertification combating plan implementation, which were observed in terms of increased agricultural productivity as a result of various water harvesting measures in districts of Jhabua and Dhar in Madhya Pradesh. The increase in areal extent of irrigated agricultural 
land was quantitatively evaluated by interpreting the satellite images. Visual interpretation of images confirms the increase in water bodies (both in number and area), consequential in agricultural expansion in surrounding areas. Increase in range and peak observations and compactness of NDVI values reveal the qualitative improvement in agricultural production. Thus, the study helps in monitoring the changes in real time, providing useful inputs for evaluating the efficiency of the recommended action plans as well as for further implementation of new strategies for environmental development. The future scope of the study includes assessment of socio-economic parameters for more accurate appraisal of sustainable developments of the region.

\section{Acknowledgements}

Authors are grateful to the two anonymous reviewers for their valuable comments which helped them to improve the paper. Authors are thankful to Sri A S Kiran Kumar, Director, Dr J S Parihar, Dy Director, Dr Manab Chakraborty, Group Director, Dr Ajai, Former Group Director, Space Applications Centre, Ahmedabad and Dr M S Nathawat, Head, Department of Geography, IGNOU, New Delhi for their support and encouragement.

\section{References}

Adiga S and Krishna Murthy Y V N 2000 Integrated sustainable development of land and water resources using space technology inputs; Space Forum 5(1-3) 179-202.

GLASOD Global Assessment of Human Induced Soil Degradation 1990 International Soil Reference and Information Centre (Wageningen, Netherlands) and UNEP (Nairobi, Kenya) 2004 http://lime.isric.nl/index.cfmcontentid_158.

IMSD Integrated Mission for Sustainable Development: Technical Guideline 1995 Mission management core team, National Remote Sensing Agency, DOS, Govt. of India, Balanagar, Hyderabad.
Jackson R D, Slater P N and Pinter P J 1983 Discrimination of growth and water stress in wheat by various vegetation indices through clear and turbid atmospheres; Rem. Sens. Environ. 15 187-208.

Jayakrishnan P V 2001 India, National action programme to combat desertification in context of UNCCD, 1, iii-iv, MoEF, Govt. of India.

Lillesand Thomas M and Kiefer Ralph W 2000 Remote Sensing and Image Interpretation, 4th edn, Chapter 7, 479-482, John Willey \& Sons Inc., USA.

MA Millennium Ecosystem Assessment 2005 Ecosystems and Human Well-being; Desertification Synthesis World Resources Institute (Washington DC).

MoEF 2001 India, National action programme to combat desertification in context of UNCCD, Chapter 6, 1 86103, MoEF, Govt. of India.

Rao K H V Durga, Rao V Venkateswara and Roy P S 2005 Water Resources Development - Role of Remote Sensing and Geographical Information System, Proceedings of 12th International Rainwater Catchment Systems Conference.

Reynolds J F, Smith D M S and Lambin E F 2007 Global desertification: Building a science for dryland development; Science 316 847-851.

SAC 1995 Integrated mission for sustainable development, land and water resources development for Dahi Block, Dhar district, Madhya Pradesh, 21p.

SAC 2007 Desertification \& Land Degradation Atlas of India, ISRO, Govt. of India, Ahmedabad.

Shankar M N R and Mohan G 2005 A GIS based hydrogeomorphic approach for identification of site-specific artificial-recharge techniques in the Deccan Volcanic Province; J. Earth Syst. Sci. 114(5) 505-514.

Tucker C J 1979 Red and photographic infrared linear combinations for monitoring vegetation; Rem. Sens. Environ. 8 127-150.

Tucker C J, Newcomb W W, Los S O and Prince S D 1991 Mean and inter-year variation of growing-season normalized difference vegetation index for the Sahel 1981-1989; Int. J. Rem. Sens. 12 1113-1115.

UNCCD 1994 United Nations Convention to Combat Desertification, Elaboration of an International Convention to Combat Desertification in Countries Experiencing Serious Drought and/or Desertification Particularly in Africa U.N.Doc.A/AC/241/27, 33 I.L.M 1328 United Nations.

Velayutham M, Mandal D K, Mandal C and Sehgal J 1999 Agro-ecological Subregions of India for Planning and Development, NBSS \& LUP, NBSS Publ. Nagpur $\mathbf{3 5}$ $12-16,28-30,87-89$. 